\title{
ІНСТРУМЕНТАЛЬНІ ОСНОВИ НАНОЕКОЛОГІЇ
}

\author{
О. І. Бондар ${ }^{1}$, В. М. Ващенко ${ }^{1}$, В. М. Ільїн ${ }^{2}$, К. А.Сахно ${ }^{3}$ \\ Аержавна екологічна академія післядипломної освіти та управління ${ }^{1}$ \\ Національна медична академія післядипломної освіти імені П. А. Шупика² \\ Експоцентр України
}

\begin{abstract}
Потрапляння наноматеріалів у навколишнє середовище - нова екологічна небезпека, яку необхідно досліджувати і мати інструментальні засоби для 'ї контролю. Існуючі традиційні прилади дослідження наноматеріалів, незважаючи на їх громіздкість, дозволяють проведення лабораторного дослідження екологічного впливу наночастинок залежно від їх характеристик. Однак для екологічних служб необхідні нові портативні інструментальні засоби та відповідна теоретична підготовка. Для оцінки екологічної безпеки будь-яких наночастинок необхідно розробити універсальний алгоритм оцінки рівня потенційної екологічної небезпеки залежно від характеристик конкретних підконтрольних наноматеріалів.
\end{abstract}

Ключові слова: наноматеріали, екологічна безпека, універсальний алгоритм.

\section{ИНСТРУМЕНТАЛЬНЫЕ ОСНОВЫ НАНОЭКОЛОГИИ}

\author{
О. И. Бондар ${ }^{1}$, В. М. Ващенко \\ В. Н. Ильин ${ }^{2}$, К. А. Сахно ${ }^{3}$ \\ Государственная экологическая академия последипломного образования и управления 1 \\ Национальная медицинская академия последипломного образования имени П. ^. Шупика \\ Экспоцентр Украины ${ }^{3}$
}

\begin{abstract}
Попадание наноматериалов в окружающую среду - новая экологическая опасность, которую необходимо исследовать и создать инструментальные средства для ее контроля. Существующие традиционные приборы исследования наноматериалов, несмотря на их громоздкость, позволяют проведение лабораторного исследования экологического воздействия наночастиц в зависимости от их характеристик. Однако для экологических служб необходимы новые портативные инструментальные средства и соответствующая теоретическая подготовка. Для оценки экологической безопасности любых наночастиц необходимо разработать универсальный алгоритм оценки уровня потенциальной экологической опасности в зависимости от характеристик конкретных подконтрольных наноматериалов.
\end{abstract}

Ключевые слова: наноматериалы, экологическая безопасность, универсальный алгоритм.

\section{INSTRUMENTAL BASES OF NANOECOLOGY}

\author{
O. I. Bondar ${ }^{1}$, V. M. Vaschenko ${ }^{1}$, V. M. Ilyin², K. A. Sahkno ${ }^{3}$ \\ State Ecological Academy of Post-Graduate Education and Management ${ }^{1}$ \\ National Medical Academy of Post-Graduate Education by P. L. Shupyk ${ }^{2}$ \\ Expocenter of Ukraine ${ }^{3}$
}

\begin{abstract}
Nanomaterials transfer into the environment is a new environmental hazard that must be investigated and the corresponding instrumental apparatus for its control must be created. The existing traditional devices of nanomaterials investigation despite their bulkiness enables preforming laboratory investigations of nanoparticles ecological impact depending on their characteristics. However new portable devices are required for ecological services. Corresponding training is also needed. For any nanoparticles ecological safety estimate an universal algorithm should be developed for estimate of potential environmental hazard level depending on characteristics of the specific nanomaterials.
\end{abstract}

Key words: nanomaterials, ecological safety, universal algorithm.

Вступ. Не зважаючи на те, що наноматеріали на сьогодні дуже швидко розповсюджуються, жоден з їх видів не вивчений в повному об'ємі екологічної безпеки для живих і рослинних біосферних організмів.

(C) О. I. Бондар, В. М. Ващенко, В. М. Ільїн, К. А.Сахно 
Багато наноматериалів мають зовсім іншу біологічну дію, яка може радикально відрізнятись від біологічної дії їх макроаналогів. Тому вони є продукцією нових видів, а це означає що оцінки їх потенційного екологічного ризику для здоров 'я людини і навколишнього середовища повинні бути обов'язковими.

Потужність експозиції для живих і рослинних об'єктів біосфери різними класами наноматеріалів неухильно зростає. Однак, існуючий на сьогодні об'єм знань про наносвіт і стан дослідницької експериментальної та вимірювальної бази не дозволяють отримати однозначні висновки щодо оцінок їх потенційних наноекологічних ризиків, пов'язаних з можливими небезпечними впливами на здоров'я людського організму на молекулярно-клітинному рівні. Це означає, що першочерговою задачею є усунення таких білих плям в знаннях шляхом створення та впровадження новітніх економічно доцільних та ефективних методів, апаратурних засобів і підходів для контролю за наявністю й динамікою наноматеріалів в біосфері та їі об'єктах.

Мета роботи полягає в обгрунтуванні розроблення універсального алгоритму оцінювання рівня потенційної екологічної небезпеки залежно від характеристик конкретних підконтрольних наноматеріалів.

Результати та їх обговорення. Здобуті на сьогодні знання по установленню токсичності наноматеріалів досить скромні. Але навіть одноразова інгаляція наночастинок $[1,2,4,8,11]$ викликає у піддослідних живих організмів запальний процес в тканинах легень $з$ можливим наступним канцерогенезом. Наноматеріали також мають нейротоксичні, кардіотоксичні і гепатотоксичні властивості [12], і здатні викликати окислювальний стрес в клітинах мозку. Є дані про негативний вплив наночастинок на згортання крові [3]. Однозначні дані щодо мутагенності, генотоксичності, канцерогенності, тератогенності, ембріотоксичності, алергенності наноматеріалів та їх гормонального й імунного впливу відсутні. Залишаються також не вивченими результати використання продуктів харчування, що містять харчові нанодомішки.

У відношенні конкретного механізму впливу наноматеріалів на об'єкти біосистем домінуючою характеристикою може бути не тільки кількість наноматеріалів, а перш за все площа їх поверхні, яка визначає їх реакційну здатність. Принципово важливою токсикологічно характеристикою $є$ їх нерозчинність у воді та біологічних середовищах.

Можна зробити висновок про те, що першочерговою задачею для екологічних досліджень та контролю нановмісних продуктів, матеріалів і середовищ $\epsilon$ розробка та створення високочутливих портативних методів та апаратурних засобів для виявлення, вимірювання та аналізу наночастинок і нанокомплексів в живих організмах, а також у навколишньому середовищі.

Розробка нових підходів, методів та апаратурного забезпечення для вирішення задач наноекології вимагає отримання вихідних даних, які завжди є основою наукових та інженерно-фізичних розробок. До таких вихідних даних слід віднести головні класифікаційні особливості для точкових, протяжних лінійних, дво- и тривимірних наночастинок. В класифікаційний список слід включити класи наночастинок за їх фізико-хімічними ознаками, а також за ознаками, що характерні для шляхів їх виробництва, так звані «висхідний» $\mathrm{i}$ «низхідний» шляхи $[1,5,6,10]$.

При розробці нових дослідних та вимірювальних методів і концепцій нової спеціалізованої дослідницької апаратури у відповідності з пріоритетністю задач і проблем у відношенні забезпечення екологічної безпеки наноматеріалів, необхідно знати також особливості їх фізико-хімічних властивостей - гранулометричний, хімічний і фазовий склад наночастинок, геометричні характеристики і питомі відношення площі поверхні наночастинок до їх маси чи розміру, а також і їх біологічного впливу $[1,5,10]$.

Слід зазначити, що до сьогодні відсутні спеціалізовані методи та апаратура для вимірювань і контролю подібних нанопараметрів. Традиційні ж експериментальні методи і апаратурні засоби є вкрай дорогими і громіздкими. Для їх експлуатації необхідні фахівці найвищої кваліфікації з відповідним досвідом роботи. До того ж, такі фахівці повинні мати додаткову спеціалізовану екологічну підготовку.

Використання в сукупності всіх перерахованих традиційних методів дозволяє вивчити закономірності взаємодії наночастинок з біологічними об'єктами на молекулярно-клітинному рівні і охарактеризувати порушення в біологічних макромолекулах, надмолекулярних комплексах, мембранах і інших біооб'єктах, які можуть виникати під впливом наноматеріалів. Отримані про цьому результати є взаємно доповнюючими в процесі аналізу потенційної екологічної небезпеки, пов'язаної з нанобіоефектами.

Екологічним же службам потрібні компактні методи і прилади для якісного екологічного експресаналізу вмістимості, властивостей та результатів впливу нанодомішок на живі організми на молекулярно-клітинному рівні.

Нові методи і засоби для забезпечення надійною інструментальною базою наноекології повинні реалізовувати експресні вимірювання числа наночастинок, 
визначати їх ідентифікацію, величину площі поверхні за умов наявності стандартизованих індикаторів нанотоксичності, які повинні обов'язково враховувати поверхневі властивості, розмір, форму, склад і хімічну реактивність наночастинок, надійно відрізняти від їхніх хімічних дисперсних макроаналогів.

Висновки. Повний системний комплекс для оцінки екологічного ризику при дії наноматеріалів на різні біооб'єкти складається 3 досить об'ємного набору фізико-хімічних, біохімічних, молекулярно-біологічних, токсикологічних тестів і додаткових спеціальних досліджень, які дозволять провести всебічну оцінку екологічних ризиків. Виходячи із тенденції швидкого розширення списку номенклатури нових створюваних наноматеріалів, нанопродуктів і нанотехнологій, для розробки сучасної методології оцін-

\section{Лтература}

1. Mammalian pharmacokinetics of carbon nanotubes using intrinsic near-infrared fluorescence / P. Cherukuri, C. J. Gannon, T. K. Leeuw [et al.] // PNAS. -2006. - Vol. 103, N 50. - P. 1888218886.

2. Kieuter J. Nanoparticles and microparticles for drug and vaccine delivery / J. Kieuter// J. Anal. - 1996. - Vol. 189, N 8, P. 503-505.

3. Systemic microvascular i dysfunction and inflammation after pulmonary particulate matter exposure / T. R. Nurkiewicz, D. W. Porter, M. Barger [et al.] // Environ. I. Health Perspect. 2006. - Vol. 1 14, N 5. - P. 412-419.

4. Oberdorster G. Nanotoxicology: an emerging discipline evolving from studies of ultrafine particles / G. Oberdorster, E. Oberdorster, J. Oberdorster // Environ. Health Perspect 2005. - Vol. 1 13, N 8. - P. 823-839.

5. Translocation of inhaled ultrafine particles to the brain / G. Oberdorster, Z. Sharp, A. P. Elder [et al.] // Inhal.Toxicol. 2004. -Vol. 16, N 4. - P. 437-445.

6. Unusual inflammatory y and fbrogenic pulmonary responses to single-walled carbon nanotubes in mice / A. A. Shvedova, E. R. Kisin, R. Mercer [et al.] // Am.J.Physiol. Lung Cell. Mol. Physiol. - 2005. - Vol. 289, N 5. - P. 698-708.

7. Oxidative stress and NF kappa B activation in the lungs of rats: a synergistic interaction between soot and iron particles ки екологічного ризику можна охарактеризувати умови, у відповідності з якими будь який новий матеріал може бути класифікований конкретним рівнем потен ційної екологічної небезпеки за спеціально розробленою шкалою, а значить і визначити його пріоритет 3 точки зору об'єму спеціальних екологічних досліджень. Тоді повний комплекс необхідних спеціальних досліджень необхідно буде проводити тільки для випадку наноматеріалів з найвищими рівнями їх екологічної небезпеки. Тому необхідно розробити конкретний універсальний алгоритм оцінки рівня потенційноі екологічної небезпеки, що базується перш за все на фундаментальних характеристиках підконтрольного наноматеріалу. Такий універсальний підхід дозволить відповісти на всі запитання відносно екологічної безпеки кожного конкретного виду наноматерії.

/ Y. M. Zhou, C. Y. Zhong, I. M. Kennedy [et al.] // Toxicol. Appl. Pharmacol. - 2003. - Vol. I90, No 2. - P.157-169.

8. Research strategies for safety evaluation of Nanomaterials. Part VIJJ. International efforts to develop risk-based safety evaluations for nanomaterials / K. Thomas, P. Aguar, H. Kawasaki [et al.] // Toxicol. Sci. - 2006. - Vol. 92, N I . - P. 23 32.

9. Research strategies for safety evaluation of Nanomaterials. Part 1I.Toxicological and safety evaluation of nanomaterials, current challenges and data needs / M. P. Holsapple, W. H. Farland, T. D. Landry [et al.] // Toxicol.Sci. - 2005. Vol. 88, Nol. - P. 12-17.

10. Research strategies for safety evaluation of Nanomaterials. Part III. Nanoscale technologies for assessing risk and improving public health / D. M. Balshaw, M. Philbert, W. A. Suk// Toxicol. Sci. - 2005. - Vol. 88, No2. - P. 298-306.

11. Research strategies for safety evaluation of Nanomaterials. Part IV. Risk assessment of nanoparticles / J. S. Tsujt, A. D. Maynard, P. C. Howard [et al.] // Toxicol.Sci. - 2006. Vol. 89, N1. - P. 42-50.

12. Research strategies for safety evaluation of Nanomaterials. Part IV. Risk assessment of nanoparticles / J. S. Tsujt, A. D. Maynard, P. C. Howard [et al.] // Toxicol. Sci. - 2006. Vol. 89, N. - P. 42-50. 